\title{
Hypoxic-Ischemic Encephalopathy after Bee Sting and Treatment with Zolpidem: A Case Report
}

\author{
Arı Sokması Sonrası Gelişen Hipoksik İskemik Ensefalopati Tedavisinde Zolpidem:
} Olgu Sunumu

\author{
Turgay Demir, Miray Erdem, Aygül Tantik, Şebnem Bıçakc1 \\ Çukurova University Faculty of Medicine, Department of Neurology, Adana, Turkey
}

\section{Summary}

Hypoxic-ischemic encephalopathy (HIE), a metabolic encephalopathy, develops as a result of cessation or reduction of oxygen and blood flow to the brain. The clinical picture may vary in severity from minimal neurologic deficits to coma. In living patients, permanent neuropsychological sequelae can develop. Herein, we present a case of HIE that occurred after anaphylactic reaction due to bee sting, which was treated with zolpidem.

Keywords: Encephalopathy, hypoxia, zolpidem

$\ddot{\mathbf{O z}}$

Hipoksik iskemik ensefalopati (HİE) beyne gelen kan akımı ve oksijenin durması ya da azalması sonucu gelişen metabolik ensefalopatidir. Klinik tablo minimal nörolojik defisitten komaya kadar değişebilir. Yaşayan olgularda kalıcı nöropsikolojik sekeller gelişmektedir. Burada arı sokması sonrası anafilaktik reaksiyona bağlı HİE gelişen ve zolpidem tedavisi ile anlamlı klinik yanıt aldı ğımız bir olgu sunulmuştur.

Anahtar Kelimeler: Ensefalopati, hipoksi, zolpidem

\section{Introduction}

The pathogenesis of hypoxic ischemic encephalopathy (HIE) has been associated with disruption of cerebral autoregulation and metabolic impairment due to hypoxia. HIE, which results from diminished or ceased oxygen and blood flow to the brain, is one of the acquired metabolic encephalopathies of the central nervous system (CNS). The most common medical causes include cardiac disorders, blood loss, reduced cerebral blood flow secondary to septic or traumatic shock, obstruction of respiratory pathways, carbon monoxide intoxication, diseases that cause paralysis of respiratory muscles or diffuse CNS injury, diseases that involve the medulla oblongata, insufficient respiration of oxygen during general anesthesia, hyperthermia, acidosis, hypoglycemia, and hypercapnia (1). Various forms of hypoxic ischemic brain injury have been described including selective neuronal necrosis, focal and multifocal ischemic necrosis, periventricular leukomalacia, parasagittal brain injury, and status marmoratus. The clinical presentation might range from minimal neurologic deficits to mild or deep coma. Clinical findings as well as radiologic, electrophysiologic, and biochemical examinations are deemed necessary to establish the diagnosis and determine the prognosis of HIE. According to recent literature, treatment consists of supportive and anti-edema measures, as well as anti-epileptics when necessary, N-methyl D-aspartate (NMDA) receptor antagonists, antioxidative agents, and zolpidem. Zolpidem is a short-acting non-benzodiazepine $(\mathrm{BDz})$ sedative-hypnotic agent of the imidazopyridine group used in the treatment of insomnia $(2,3)$.

In this manuscript, we report our clinical experiences of zolpidem treatment in a case of HIE secondary to anaphylactic reaction due to bee sting.

Address for Correspondence/Yazışma Adresi: Turgay Demir MD, Çukurova University Faculty of Medicine, Department of Neurology, Adana, Turkey Phone: +905064004722 E-mail: drtdemir@gmail.com

Received/Geliş Tarihi: 15.04 .2015 Accepted/Kabul Tarihi: 18.07 .2015

(c) Turkish Journal of Neurology, Published by Galenos Publishing House.

This article is distributed under the terms of the "Creative Commons Attribution NonCommercial 4.0 International Licence (CC BY-NC 4.0)". 


\section{Case Report}

A woman aged 53 years with right hand dominancy was internalized at the neurological intensive care unit after bee sting on the chin followed by swelling of the face and tongue, insensible speech, and finally unconsciousness. The medical history revealed that the patient had not been stung by a bee before. In the neurologic examination, the patient had stupor, no verbal response, isocoric pupils, bilaterally positive direct and indirect light reflexes, bilaterally minimal motor response to painful stimuli, bilaterally positive Babinski, Hoffmann, Tromner, snout, and palmomental reflexes. Her body temperature was $36.0{ }^{\circ} \mathrm{C}$, blood pressure $120 / 80 \mathrm{mmHg}$, respiratory rate $30 / \mathrm{min}$, pulse $80 / \mathrm{min}$, and $\mathrm{O} 2$ saturation was $95.1 \%$. Her aspartate aminotransferase and alanine aminotransferase were mildly elevated, whereas her complete blood count was within normal ranges in routine biochemical examination. Intracerebral edema was determined in cranial computerized tomography imaging performed in the acute period (Figure 1). Lumbar puncture was performed and examination of the cerebrospinal fluid (CSF) revealed the protein level was 56 $\mathrm{mg} / \mathrm{dL}, \mathrm{CSF}$ opening pressure was $12 \mathrm{~cm} \mathrm{H}_{2} \mathrm{O}$, no cells were seen in microscopic examination, and CSF cytology was insignificant. Cerebral cortical signal abnormalities and contrast enhancement were observed bilaterally in basal ganglia, though predominant on the right, in cranial magnetic resonance imaging performed on the second day of admission (Figure 2A, B). Electroencephalography (EEG) performed on the day of admission revealed diffuse disorganization of background activity consisting of slow waves (Figure 3). The patient was provided with supportive therapy. No epileptic seizures were observed. The patient was diagnosed as having HIE, and amantadine intravenous infusion therapy was initiated at $200 \mathrm{mg} /$ day dosage. However, amantadine therapy had to be ceased at day 5 upon the observation of tachycardia, hypothermia, severe sweating, flushing, and stereotypical mouth and straining movements. The latter symptoms disappeared with the cessation of amantadine therapy. In her final neurologic examination, the patient had spontaneously opened eyes, insensible
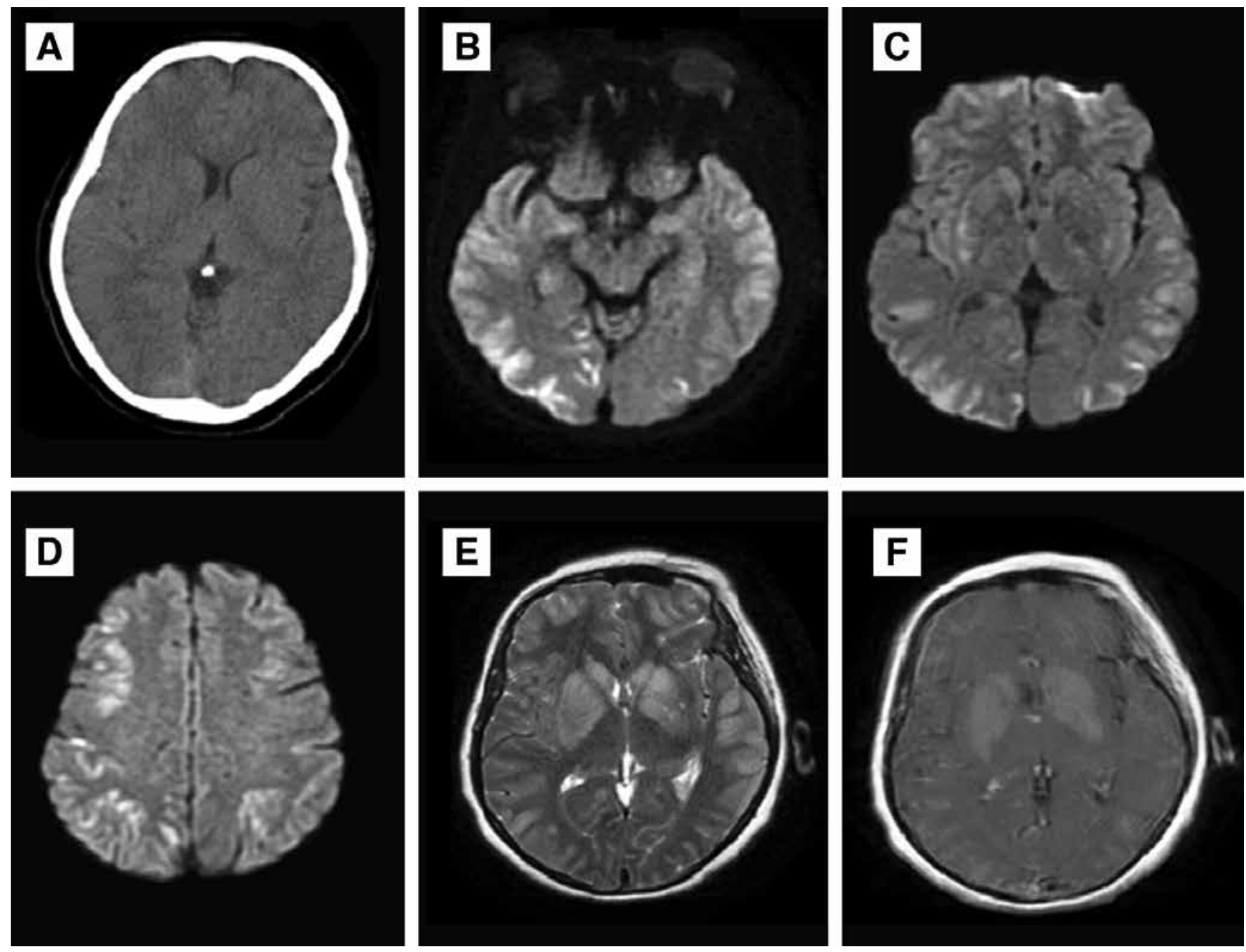

Figure 1. Acute period cerebral computed tomography and magnetic resonance imaging, diffusion magnetic resonance imaging. A) Bilateral sulcal effacement more remarkable on the right in cerebral computed tomography. B, C, D) Bilateral cortical signal pathologies more remarkable on the right. E, F) Bilateral signal and contrast enhancement on nucleus caudatus, globus pallidus and putamen 

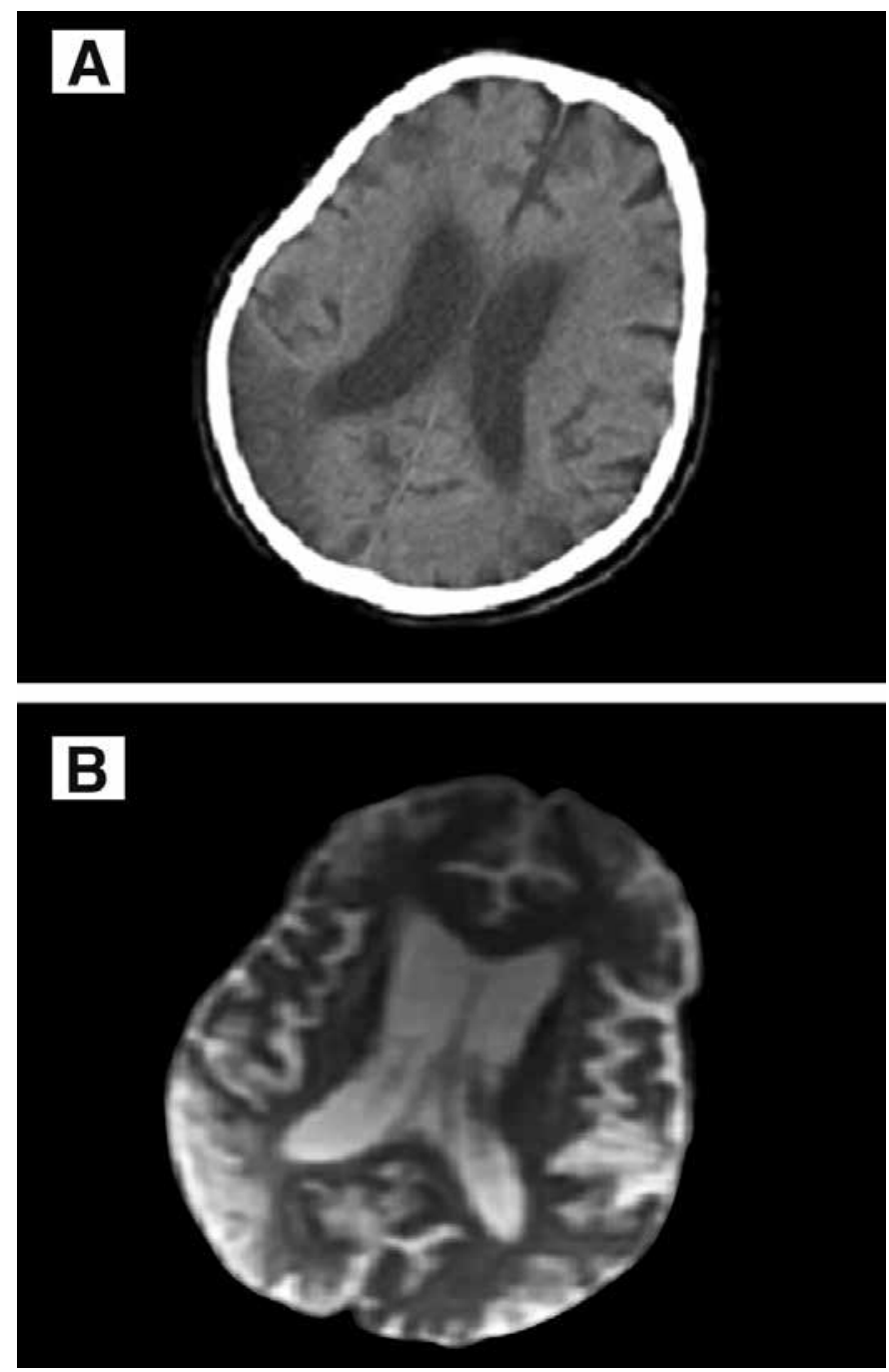

Figure 2. Control cerebral computed tomography and magnetic resonance imaging at eleven months. A) Enlarged lateral ventricles and right side dominant bilateral posterior parietal hypodensity on cerebral computed tomography. B) Diffuse cortical atrophy and right side dominant bilateral posterior parietal hyperintense lesions on magnetic resonance imaging

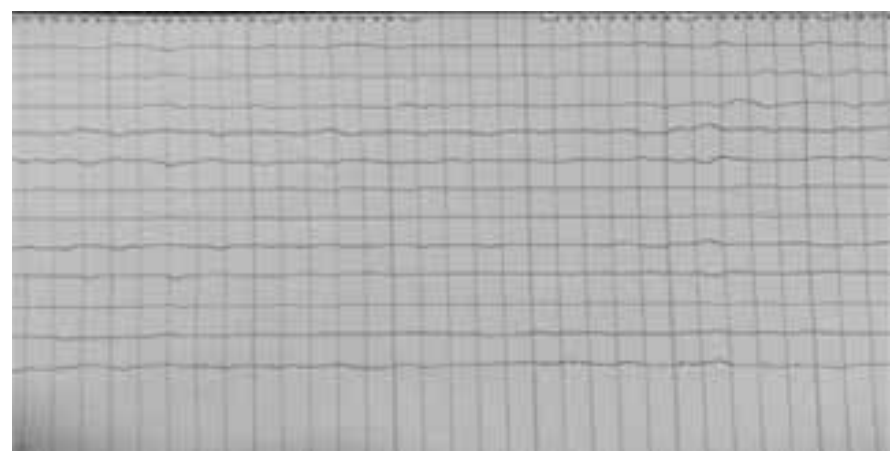

Figure 3. Electroencephalography revealed diffuse disorganization of background activity consisting of slow activity sounds in the form of moaning, actively mobile four extremities, and bilaterally positive Babinski, Hoffmann, Tromner, snout and palmomental reflexes. The patient was being fed using a percutaneous endoscopic gastrostomy feeding tube at discharge.

Oral zolpidem therapy at $10 \mathrm{mg} /$ day dosage was initiated at discharge. Follow-up examinations in the outpatients' clinic showed that the patient had better vigilance and speech with use of more words, and marked mood changes. The improvement process followed a stationary course afterwards. At one year, the patient attempted to follow simple commands, had sensible emotional responses, and partial verbal interaction in addition to continued stereotypical mouth movements, bilateral signs of irritation of the pyramidal tract, attempted to preserve posture with support, and had limited oral intake.

\section{Discussion}

HIE has been defined as the cease of cranial oxygen and blood supply due to cardiac and circulatory or respiratory failure. Patients might remain in a permanent coma or for prolonged periods after a severe brain injury. The vegetative state after days- or weeks-long coma might turn into minimal consciousness $(4,5)$. The clinical picture most commonly occurs following cardiac arrest in adults and neurologic complications occur due to ischemia and acidosis. The rates of mortality and morbidity are quite high in HIE $(6,7)$. Ischemia and hypoxia damages brain function at varying degrees and advanced stages of ischemia results in selective and permanent injury to cortical neurons. The degree of neuronal injury secondary to global cerebral ischemia is associated with the duration of exposure to hypoxia, cerebral blood flow, body temperature, and blood glucose level $(8,9)$. Duration of cardiac arrest is the most important determinant of prognosis, and cease of cerebral circulation for 4-5 minutes is known to cause permanent brain injury. Approximately half of all HIE survivors are left with moderate to severe neuropsychologic sequels (10).

Medical history, examination, neuroimaging, EEG and biochemical tests aid in diagnosis. Patients diagnosed with HIE should be followed in the intensive care unit or neurologic intensive care unit in the acute period. Rapid improvement in cognitive function is often seen in the initial weeks following anoxic injury; however, only minimal cognitive improvement is seen in most cases. The disease course plateaus in the next 3-month period. Moderate to severe memory loss is seen in almost half of survivors, which significantly affects the quality of life of both the patient and their caregivers.

The currently available treatment options in HIE include amantadine, zolpidem, and baclofen. These CNS stimulants have been shown to provide a dramatic improvement in HIE treatment in individual case reports (11); however, serial studies are lacking in this respect.

Amantadine exerts a dopaminergic effect through the antagonistic effect on NMDA. In addition to its use in the treatment of influenza and Parkinson's disease, amantadine has recently been used in the treatment of impaired consciousness. The agent exerts its effects on vigilance by helping reduce the NMDArelated calcium channel-dependent post-synaptic membrane potential in target neurons via the glutamatergic pathway (12). A patient was reported in the literature who arrested due to 
ventricular fibrillation and regained spontaneous circulation at 20-25 minutes, and could stand with assistance at 22 days following amantadine sulphate infusion between days 11 and 22. Additionally, significant improvement in consciousness has been reported following amantadine infusion in a patient with meningoencephalitis who remained in a coma for 10 days $(13,14)$. Amantadine infusion was also the first choice in the treatment of our patient; however, the infusion had to be diminished and eventually ceased due to the development of drug-related adverse effects including uncontrollable tachycardia, hyperthermia, excessive sweating, flushing, stereotypical mouth and straining movements on day 5. These clinical findings disappeared following the cessation of amantadine infusion.

Entered clinical practice in 1988 and is a sedative hypnotic drug of $\mathrm{BDz}$ group. It exhibits its effects by opening chloride channels via allosteric effects through binding to the alpha-1 subunit of gamma-aminobutyric acid receptor complex (15). Zolpidem is used in the short-term treatment of insomnia, as well as jet-lag treatment, and has a lower addiction and deprivation potential compared with BDz. Zolpidem is thought to have positive effects on vigilance and cognition in patients with impaired consciousness. However, the exact pathophysiologic mechanism beneath this paradoxic effect is not known. Some authors have suggested that the effects of zolpidem might be associated with the diaschisis phenomenon $(16,17,18)$. Studies using single-photon emission computed tomography, positron emission tomography, and EEG following zolpidem therapy have reported changes in brain activity (prefrontal cortex, thalamus and striatum) $(19,20)$. Zolpidem is currently available in 5 and $10 \mathrm{mg}$ tablet forms (Ambien), but not in Turkey. The recommended treatment dosage is $10 \mathrm{mg} /$ day, which should be reduced to $5 \mathrm{mg}$ /day at ages $>65$ years. The CNS depressive effect of zolpidem is reversible with the antagonist agent flumazenil, similar to BDzs (10).

Our patient was first treated with parenteral amantadine, which was ceased at day 5 due to adverse effects. Next, zolpidem was started at discharge and enhanced communication, attempts to obey simple commands, limited verbal response, maintenance of posture with support, and limited oral nutrition were gained in the long term.

Consequently, zolpidem is thought to be effective in the treatment of patients with diffuse cerebral injury, including those in a vegetative state or with minimal consciousness. It should always be noted that zolpidem therapy might positively influence the clinical picture in cases of HIE where parenteral amantadine therapy cannot be used. Our information regarding the use of zolpidem in cases of HIE should be supported with reports of further experience.

\section{Ethics}

Informed Consent: Informed consent was taken from the patient. Peer-review: Externally peer-reviewed.

\section{Autborship Contributions}

Surgical and Medical Practices: Turgay Demir, Miray Erdem, Şebnem Brçakcı, Concept: Turgay Demir, Aygül Tantik, Design: Turgay
Demir, Miray Erdem, Data Collection or Processing: Miray Erdem, Aygül Tantik, Analysis or Interpretation: Turgay Demir, Sebnem Bıçakcı, Literature Search: Turgay Demir, Aygül Tantik, Miray Erdem, Writing: Turgay Demir.

Conflict of Interest: No conflict of interest was declared by the authors.

Financial Disclosure: The authors declared that this study has received no financial support.

\section{References}

1. Özışık Karaman H. İskemik-Hipoksik (İskemik-Anoksik) Ensefalopati. Turkiye Klinikleri Cerrahi Tip Bilimleri Dergisi 2007;3:49-54.

2. Langtry HD, Benfield P. Zolpidem. A review of its pharmacodynamic and pharmacokinetic properties and therapeutic potential. Drugs 1990;40:291-313.

3. Sanger DJ. The pharmacology and mechanisms of action of new generation, non-benzodiazepine hypnotic agents. CNS Drugs 2004;18 Suppl 1:9-15; discussion 41, 43-15.

4. Laureys S, Celesia GG, Cohadon F, Lavrijsen J, Leon-Carrion J, Sannita WG, Sazbon L, Schmutzhard E, von Wild KR, Zeman A, Dolce G, European Task Force on Disorders of C. Unresponsive wakefulness syndrome: a new name for the vegetative state or apallic syndrome. BMC Med 2010;8:68.

5. Giacino JT, Ashwal S, Childs N, Cranford R, Jennett B, Katz DI, Kelly JP, Rosenberg JH, Whyte J, Zafonte RD, Zasler ND. The minimally conscious state: definition and diagnostic criteria. Neurology 2002;58:349-353.

6. Geocadin RG, Koenig MA, Jia X, Stevens RD, Peberdy MA. Management of brain injury after resuscitation from cardiac arrest. Neurol Clin 2008;26:487-506.

7. VR, Verbunt JA, van Heugten CM, Wade DT. Cognitive impairments in survivors of out-of-hospital cardiac arrest: a systematic review. Resuscitation 2009;80:297-305.

8. Busto R, Dietrich WD, Globus MY, Ginsberg MD. The importance of brain temperature in cerebral ischemic injury. Stroke 1989;20:1113-1114.

9. Longstreth WT, Jr. Diehr P, Cobb LA, Hanson RW, Blair AD. Neurologic outcome and blood glucose levels during out-of-hospital cardiopulmonary resuscitation. Neurology 1986;36:1186-1191.

10. Roine RO, Kajaste S, MK. Neuropsychological sequelae of cardiac arrest. J Am Med Assoc 1993;269:237-242.

11. Pistoia F, Mura E, Govoni S, Fini M, Sara M. Awakenings and awareness recovery in disorders of consciousness: is there a role for drugs? CNS Drugs 2010;24:625-638.

12. Saniova B, Drobny M, Kneslova L, Minarik M. The outcome of patients with severe head injuries treated with amantadine sulphate. J Neural Transm (Vienna) 2004;111:511-514.

13. Wu TS, Garmel GM. Improved neurological function after Amantadine treatment in two patients with brain injury. J Emerg Med 2005;28:289-292.

14. Aksu NM, Şenlikçi H, Akkaş M, Özmen MM. The Neurologic İmprovement of a patient after amantadine infusion. Akademik Acil Tip Olgu Sunumları Dergisi 2013;4:161-163.

15. Hajak G, Muller WE, Wittchen HU, Pittrow D, Kirch W. Abuse and dependence potential for the non-benzodiazepine hypnotics zolpidem and zopiclone: a review of case reports and epidemiological data. Addiction 2003;98:1371-1378

16. Cohen L, Chaaban B, Habert MO. Transient improvement of aphasia with zolpidem. N Engl J Med 2004;350:949-950.

17. Clauss R, Sathekge M, Nel W. Transient improvement of spinocerebellar ataxia with zolpidem. N Engl J Med 2004;351:511-512.

18. Clauss RP, Nel WH. Effect of zolpidem on brain injury and diaschisis as detected by $99 \mathrm{mTc}$ HMPAO brain SPECT in humans. Arzneimittelforschung 2004;54:641-646.

19. Clauss RP, Guldenpfennig WM, Nel HW, Sathekge MM, Venkannagari RR. Extraordinary arousal from semi-comatose state on zolpidem. A case report. $S$ Afr Med J 2000;90:68-72.

20. Brefel-Courbon C, Payoux P, Ory F, Sommet A, Slaoui T, Raboyeau G, Lemesle B, Puel M, Montastruc JL, Demonet JF, Cardebat D. Clinical and imaging evidence of zolpidem effect in hypoxic encephalopathy. Ann Neurol 2007;62:102-105. 